\title{
PREY SELECTION BASED ON PREDATOR/PREY WEIGHT RATIOS FOR COMMON FISHES OF NORTHWEST ARABIAN GULF
}

\author{
SELEKCJA OFIAR USTALONA, NA PODSTAWIE STOSUNKU \\ MASY OFIARY DO MASY DRAPIEŻNIKA, DLA PODSTAWOWYCH \\ GATUNKÓW RYB WYSTĘPUJĄCYCH W WODACH \\ PÓLNOCNO-ZACHODNIEJ CZEŚCI ZATOKI PERSKIEJ
}

\author{
Department of Marine Vertebrate, Marine Science Centre, University of Basrah, Iraq
}

\begin{abstract}
As part of a comprehensive study concerning the trophic interrelationship of fish assemblage in the Northwest Arabian Gulf, the: characteristic ratios of predator-prey weights for 12 common species were calculated, This technique was used to assess the prey size selection by predator fish. Three preference modes of prey size were obtained. The first represents specialized predation on large prey, the second includes species showing less specialisation to select large prey. The third has exhibited specialisation for selection of small prey.
\end{abstract}

\section{INTRODUCTION}

The selection of individual prey by a predator depends on many factors, which may broadly divided into two categories. The first concerns both physical attributes of the prey, such as size, shape, colour, odour ... etc., and the prey behaviour. The second involves the visual acuity, swimming speed and degree of hunger of the predator. Size as a controlling factor in prey preference by fish is well documented [Ursin 1973; Werner and Hall 1974; Kislalioglu and Gibson 1975,1976; Moore and Moore 1976; Pearre 1982; Main 1985]. The importance of predation as a biological factor influencing the structure of natural community has been a central issue of community ecology. Moreover, recent studies have shown, that predation could be a major organizing force within marine communities [Bih et al. 1985; Kitching 1986]. The intent of this paper was to examine the prey selection on the basis of prey size of the common group of Northwest Arabian Gulf fish in order to assess the food resources participating among this fish assemblage. 


\section{MATERIAL AND METHODS}

The food habits data utilized in this study were collected as a part of a comprehensive study of trophic interrelationships of the demersal fish assemblage in the Northwest Arabian Gulf [Ali et al. 1993].

Fishes were collected during bottom trawling operations by the research vessel "Jamiat Al-Basrah" in the Northwest Arabian Gulf (Fig. 1) from January to August 1990. The depth of the fishing ground ranged between 6-14 m, and its sediments is a mixture of sand, silty sand, clayed sand and sand-silt-clays [Darmoian and Lindquist 1988]. Fishing operations have been undertaken at a day time for bout 3 hours for each trawl. The trawl was approximately $55 \mathrm{~m}$ long and measured $25 \mathrm{~m}$ on the foot rope, being constructed of $36 \mathrm{~mm}$ streched mesh webbing in the wings and $18 \mathrm{~mm}$ in the codend. Fish were immediately frozen after processing.

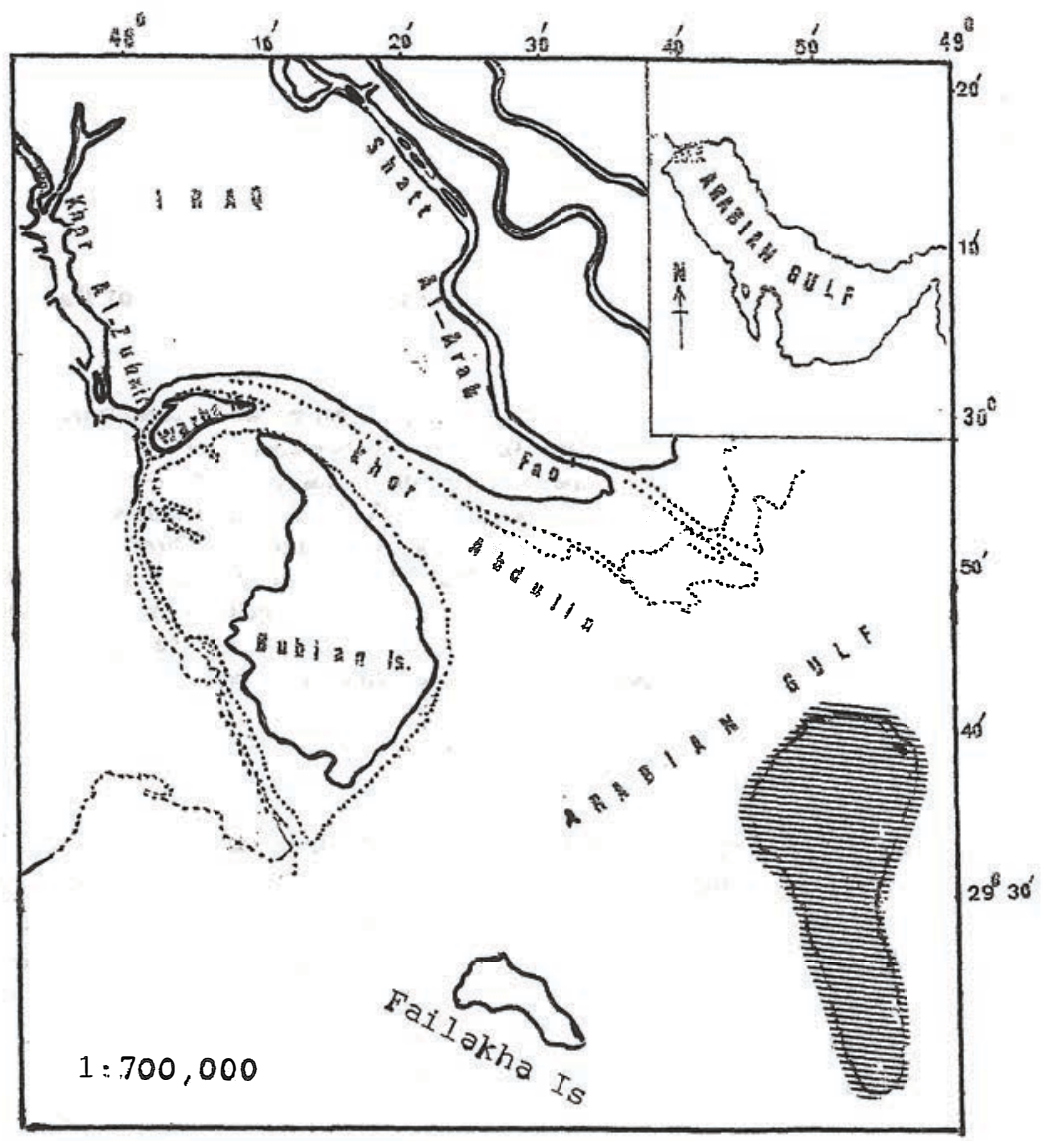

Fig. 1. Map of Northwest Arabian Gulf showing location of sampling area 
The stomachs of 2457 specimens, belonging to 12 species (rays species were treated as one species, so were the sharks) illustrated in Table 1, were analyzed. Fish were measured (standard length $+1 \mathrm{~mm}$ ) and weight $(+1 \mathrm{mg})$. The total wet weight $(\mathrm{W})$ and total numbers $(\mathrm{N})$ of each prey type were recorded for each predator. The mean individual weight of small prey $(\mathrm{W} / \mathrm{N})$ was calculated and used in the analysis as (Wpy).

Table 1

The length range $(\mathrm{cm})$ of fish species investigated and their abundance in the Northwest Arabian Gulf during 1989-1990

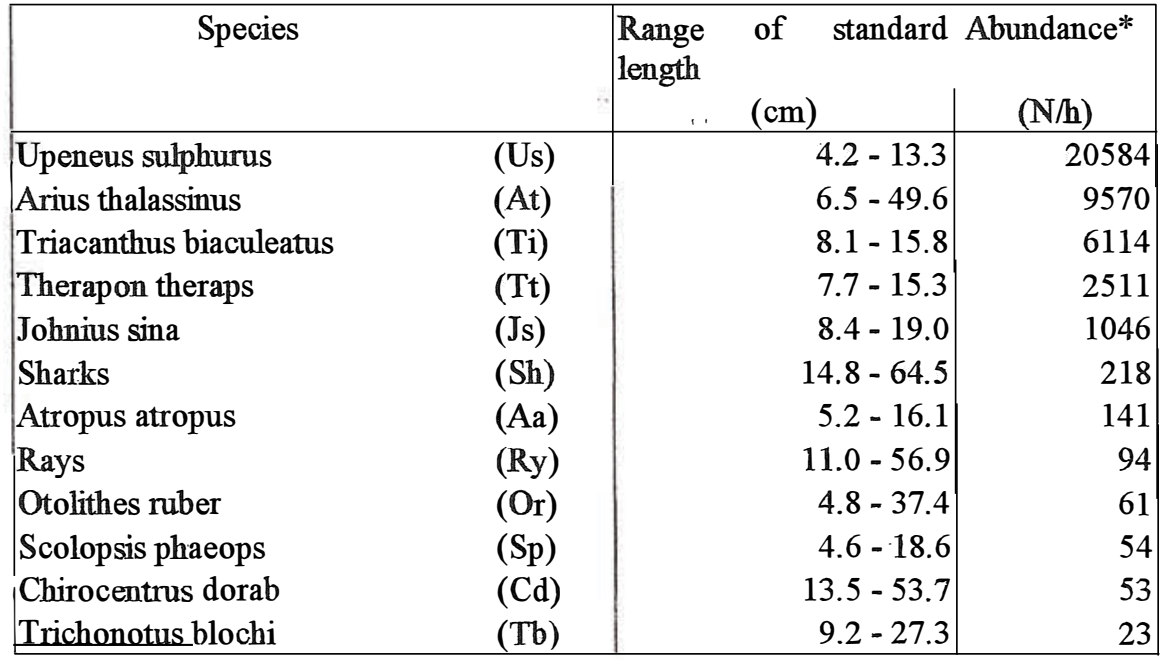

* (Ali 1993)

Prey size preference was described as prey weight (Wpy) relatively to predator weight (Wpr). The relative weight of each individual prey to each predator's stomach was calculated as a ration of predator to prey weight $(\mathrm{Wpr} / \mathrm{Wpy})$ and designed as a score. To reduce the wide range of predator and prey sizes, the logarithmic ratio (ln Wpry/Wpy) was used. The $e=1000$, so a score 7 was used as an indicator to distinguish predators feeding on large prey from those feeding on small prey. There was a bias in our calculations for some cases, due to the fact that no attempt was made to correct prey weights for the degree of digestion. However, the individual weights rather than the mean ones have been recorded for prey items which could accurately determined their number. The standard deviations were calculated as a feeding selectivity factor. A small standard deviation indicates a strong preference to a narrow range of prey sizes and vice versa. A plot of the mean scores against the standard deviations indicates the predator mean target size and the selectivity within the prey size spectrum.

\section{RESULTS}

Figure 2 illustrates the frequency distribution of scores for 12 species investigated. The curves of the first three species (A.atropus, T.biaculeaus and rays) were shifted to the right of the dash line (score 7). However, the curves of the rest of species were gradually shifted to the left. 

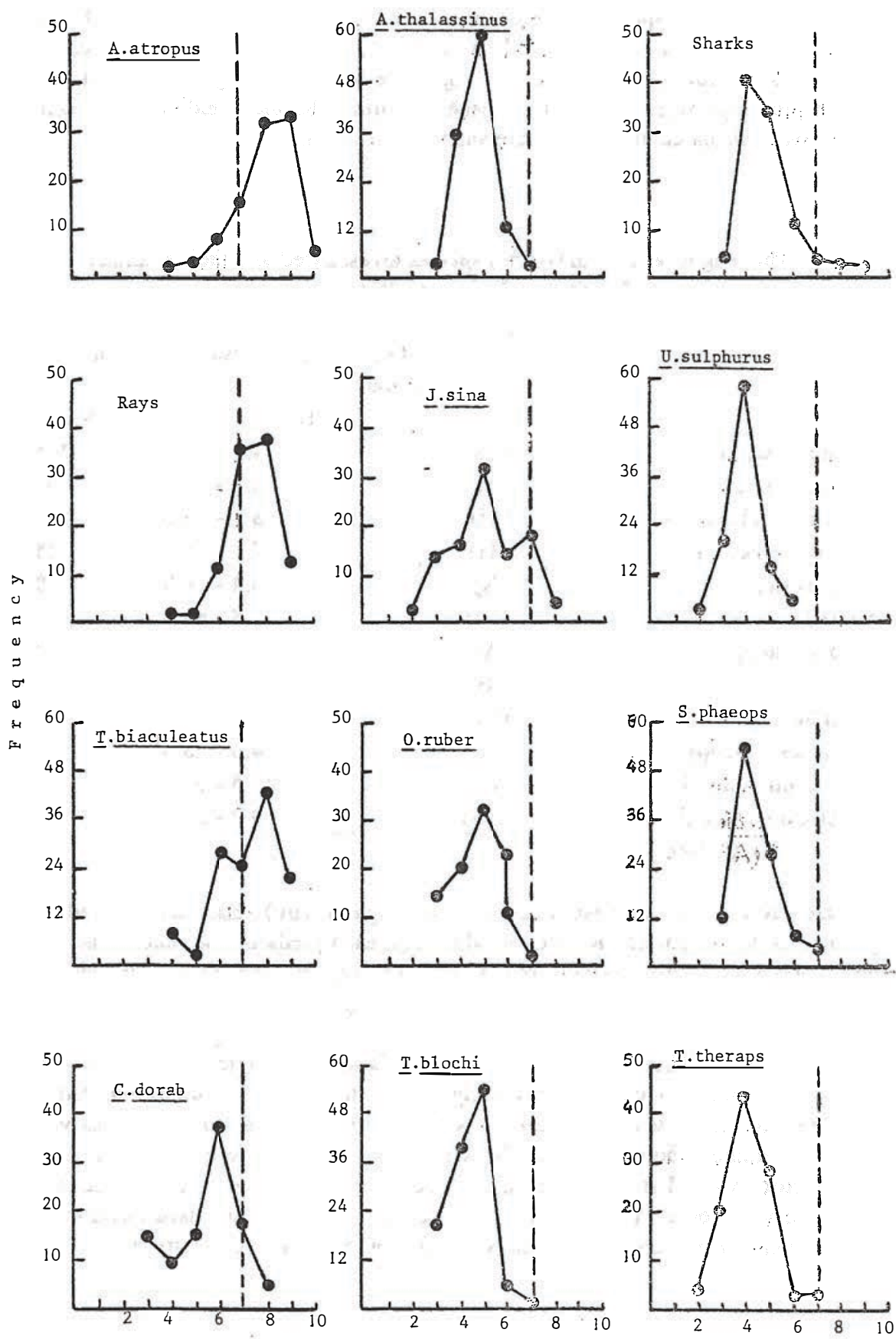

S c o r e s

Fig. 2. Frequency distributions of preadator/prey scores for the (12) common fish species in the Northwest Arabian Gulf 
It means, that the first three species fed mainly on smaller prey comprised between $1 / 3000$ $1 / 8000$ of their weights The other nine species were mainly feeding on relatively larger prey and could be divided into following groups:

I. C.dorab (had a modal score of $6 \mathrm{e}=403.4$ ), i.e. the prey was generally $1 / 400$ of its own size.

II. A.thalassinus, J.sina, O.ruber and T.blochi (had a modal score of 5, e=148.4) indicates, that they mainly consumed prey of size not less than $1 / 150$ of their own size.

III. U.sulphurus, S:phaeops, T.theraps and sharks; they fed heavily on large prey (score 4, $\mathrm{e}=48.4$ ) which were about $1 / 50$ of their own size. The values of 12 species plotted in Fig. 3 may be arranged into three general feeding groups. Group A located in the upper left quadrate includes J.sina, C.dorab, O.ruber and sharks. These species were of less specialization to select large prey. They fed mainly on small fish and to a lesser extent on shrimp [Ali et. al. 1993]. Group B occurring in the lower left quadrate includes T.theraps, U. sulphurus, S.phaeops, T.blochi and A.thalassinus. This group showed more specialization to select larger prey in relation to their size. Sea cucumber was the main food item for the first, while for the second and the third shrimp and crab were the favourable food, however the crabs constituted a major part ( $>96 \%)$ of food for the last two [Ali et al 1993]. Group C in the lower right quadrate includes A.atropus, T.biaculeatus and rays. These species specialized to select small prey. The first fed basically on copepods and the last two preyed on small molluscs, which contributed to $65 \%$ of their diet [Ali et al. 1993].

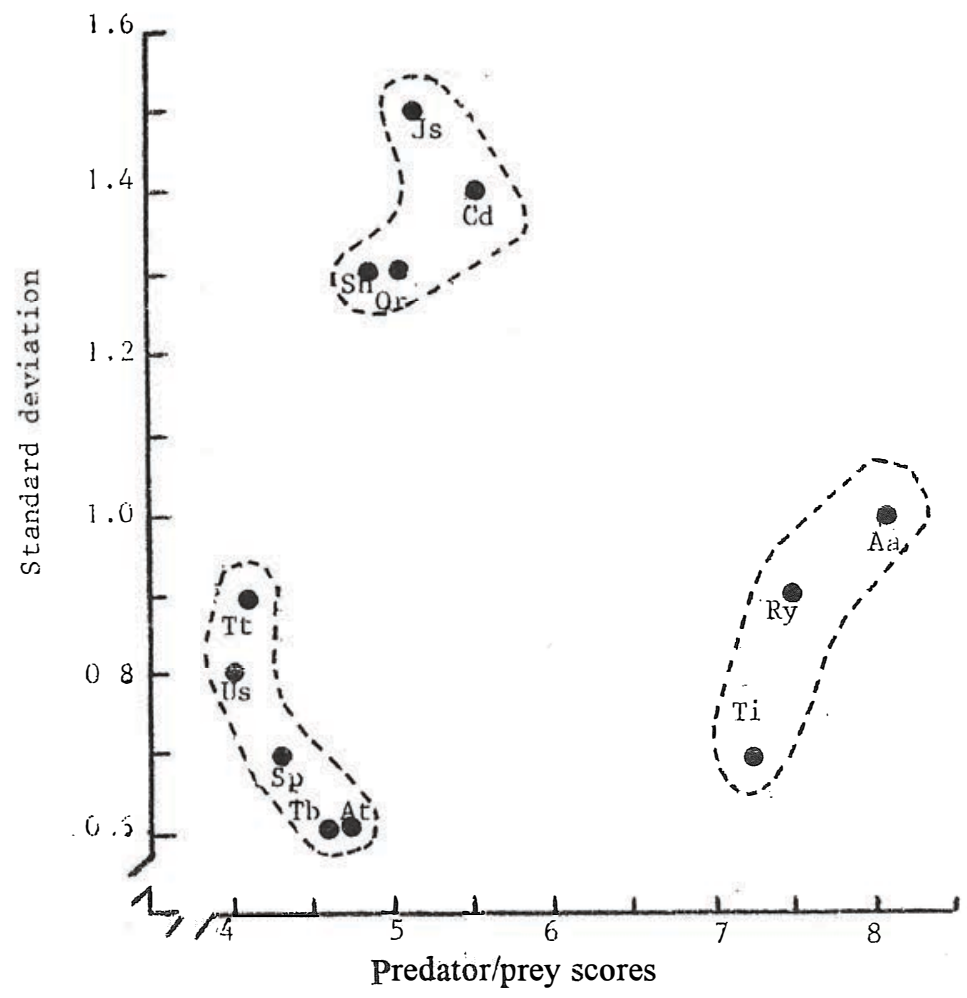

Fig. 3. Plot of mean predator/prey scores versus standard deviation 


\section{DISCUSSION}

The studies dealing with the food and feeding habits of Iraqi marine fishes were mostly restricted to those inhabiting Khor Al-Zubair [Hussain and Ali 1987; Naama et al. 1989; Yousif and Naama 1992; Hussain and Naama 1992; Hussain et al. 1994]. Khor Al-Zubair is an extension of the Arabian Gulf waters in the Iraqi land. The present paper is part of a comprehensive study focused on trophic interrelationships of the demersal fish assemblage in the Iraqi marine waters of the Northwest Arabian Gulf [Ali et. al. 1993]. The analytical methods used in previous studies depended either on diet composition or gut morphology to categorize the feeding types of the investigated fish. The techmique used in the present study was to quantify the feeding types by correlation between predator-prey size scores and predators, food habit therefore the comparisons are by no mean valuable. The peakes of frequency distributions of scores in Fig. 2 may indicate, that predators are either specialized to select small prey in relation to their sizes as for A.atropus, T.biaculeatus and rays, or more or less specialized to select larger prey as for the rest of species. Such conclusion demonstrates, that in no case the generalized feeder for size selection have been obtained among the 12 common investigated species. On the other hand, Ali et al. [1993] stated that that fish assemblage in the Northwest Arabian Gulf depends on not more than two major food items, however, the food resources were well partitioned among the fish assemblage.

Thus, the preference of certain size to certain prey may indicate, that the food selection seems to be a common feature of the fish assemblage in the Northwest Arabian Gulf.

\section{ACKNOWLEDGEMENTS}

I would like to thank Dr. S.Grabe, Collier County Pollution Control Dept., Florida, USA, for reading the manuscript.

\section{REFERENCES}

Ali T.S., 1993: Composition and seasonal fluctuations in fish assemblage of the Northwest Arabian Gulf, Iraq. Marina Mesopotamica, 8 (1): 119-135.

Ali T.S, A.R.M.Mohamed, N.A.Hussain, 1993: Trophic interrelationships of demersal fish assemblage in the Northwest Arabian Gulf, Iraq. Asian Fish. Sci. 6: 255-264.

Darmoian S.A., K.Lindquist, 1988: Sediments in the estuarine environment of the Tigris-Euphrates delta, Iraq. Arabian Gulf. Geol. J.23: 15-37.

Hussain N.A., T.S.Alî, 1987: Some biological aspects of Thryssa hamiltoni and Thryssa mystox in Khor Al-Zubair, Northwest Arabian Gulf. Indian J. Fish. 34: 152-162.

Hussain N.A., A.K.Naama, 1992: On the morphology of the alimentary tract of some fishes from Khor A1-Zubair, Northwest Arabian Gulf, Iraq. J. Appl. Ichthyol. 8: 240-245.

Hussain N.A., A.K.Naama, T.S.Ali, 1994: Feeding relationships of subtropical coastal fish assemblage in Knor Al-Zubair, Northwest Arabian Gulf, Iraq. Marina Mesopotamica (In press).

Kislalioglu M., R.N.Gibson, 1975: Field and laboratory obseryations on prey-size selection in Spinachia spinachia (L.). In. Proc. $9^{\text {th }}$ Europ. Mar. Biol. Symp., edited by H.Barnes, The Aberdeen University Press, Aberdeen, 29-41.

Kislalioglu M., R.N.Gibson, 1976: Some factors governing prey selection by the 15-spined stickle Spinachia spinachia (L.). J. exp. Mar. Biol. Ecol. 25: 159-169. 
Kitching R.L.s 1986: Prey-predator interactions. In: Community Ecology: Patterns and process, edited by J.Kikkawa and D.J.Anderson, Blackwell Sci publ., London, 214-239.

Main K.L., 1985: The influence of prey identity and size on selection of prey by two marine fishes. J. exp. Mar. Biol. Ecol. 88: 145-152.

Moore J.W., I.A.Moore, 1976: The basis of food selection in some estuarine fishes: Eels, Anquilla anquilla (L.); whiting, Merlangus merlangus (L.); sprat, Sprattus sprattus; and stickleback, Gasterosteus aculeatus (L.). J. Fish Biol. 9: 375-390.

Naama A.K., U.H.Yousif, N.A.Hussain, 1989: Age, growth and food of Arius thalassinus (Rupp.) from Khor Al-Zubair, Northwest Arabian Gulf. Marina Mesopotamica, 4: 129-142.

Pearre S.Jr., 1982: Estimating prey preference by predators: Uses of various indicates, and proposed of another based O X. Can. J. fish. Aquat. Sci. 39: 914-923.

Sih A., P.Crowley, M.McPeek, J.Petranka, K.Strohmeier, 1985: Predation, competition and prey communities: a review of field experiments. Ann. Rev. Ecol. Syst., 16, 269-311.

Ursin E., 1973: On the prey size preference of cod and dab. Meddr. Danm. Fisk-og Havunders., N.S. 7: 85-98.

Werner E.E., D.J.Hall, 1974: Optional foraging and the size selection of prey by the bluegill sunfish (Lepomis macrochirus). Ecology, 55: 1042-1052.

Yousif U.H., A.K.Naama, 1992: Biological study of Johnius belangerii [Cuvier 1830] and Johnieops sina [Cuvier 1830] from Khor Al-Zubair, Northwest Arabian Gulf. Marina Mesopotamica, 7 (2) (In press).

\section{SELEKCJA OFIAR USTALONA, NA PODSTAWIE STOSUNKU MASY OFIARY DO MASY DRAPIEŻNIKA, DLA PODSTAWOWYCH GATUNKÓW RYB WYSTĘPUJACYCH W WODACH PÓŁNOCNO-ZACHODNIEJ CZEŚSI ZATOKI PERSKIEJ}

\section{STRESZCZENIE}

W ramach szerzej zakrojonych badań, nad zależnościami pokarmowymi w zbiorowościach ryb północno-zachodniej części Zatoki Perskiej, wyznaczono wartości stosunku masy drapieżców i masy ofiar u 12 gatunków ryb. Podstawą do ich wyznaczenia była analiza zawartości przewodów pokarmowych 2757 osobników. Rekiny i płaszczki potraktowano jak jeden gatunek. 
Wyróżniono trzy typy preferencji drapieżców w stosunku do wielkości zjadanych ofiar:

- pierwszy charakteryzuje ryby wyspecjalizowane w zjadaniu dużych ofiar (5 gatunków), drugi charakteryzuje ryby w mniejszym stopniu wyspecjalizowane w zjadaniu dużych ofiar (4 gatunki),

- trzeci charakteryzuje ryby wykazujące tendencję do wybierania ofiar o małych rozmiarach (3 gatunki).

Received: 1994.04.06

Author's address: :

T.S. Ali

Department of:Marinee Vertebrate

Marine Sciefice Centre

University of Basrah

Iraq 